\title{
The students' ecological and legal culture of professional socialization
}

\author{
Pavel R. Abbasov ${ }^{1}$, Elena V. Abbasova ${ }^{2,3}$, Rimma A. Litvak ${ }^{1}$, Marina B. Balikaeva ${ }^{4 *}$ and Anatoliy A. Pavlichenko ${ }^{5}$ \\ ${ }^{1}$ Chelyabinsk State Institute of Culture, 454091 Chelyabinsk, Russia \\ ${ }^{2}$ Russian Presidential Academy of National Economy and Public Administration, 454091 Chelyabinsk, Russia \\ ${ }^{3}$ South Ural Institute of Management and Economics, 454084 Chelyabinsk, Russia \\ ${ }^{4}$ Tyumen Industrial University, 625002 Tyumen, Russia \\ ${ }^{5}$ Department of education, 110111 Kostanay, Kazakhstan
}

\begin{abstract}
The article reveals the urgency of addressing the students' ecological and legal culture of professional socialization. There are socio-political, institutional-organizational and psychological-pedagogical factors of the problem. The article is devoted to the ecological and legal culture in the socio-cultural environment. The environmental education includes a development of personal environmental values in the socio-cultural development. The environmental education as a component of socialization is a means of the educational environment. The ecological and legal culture of students is a complex socio-cultural and psycho-pedagogical problem of the search for perspective directions and technologies in educational environment. The environmental education should have a structure in the education system.
\end{abstract}

\section{Introduction}

The global problems are a new paradigm of youth social formation, the environmental component of the education direction. The social development of students is an important problem of pedagogics. This problem includes opportunities and ways of professional growth, systematization of personal relationships, a capital and economic sustainability. According to the latest sociological surveys in various Russian regions (Ural, Far East, etc.), students prefer an environmentally friendly place. Consequently, some young people drew attention to problems of ecology and environment. However, the desire of students and young people is passive by nature to live in the environmentally friendly place, which allows avoiding environmental problems. That is why it is necessary for them to have an environmental education.

The problems of students' environmental legal education include some factors. They are a sociopolitical factor of students' legal education, an institutional and organizational factor of the specialized development forms, a psycho-pedagogical factor of the attitude to nature.

Modern problems of ecological education actualize the following research areas: the analysis of continuity and the consistency in environmental education and the education of an individual; the value of the ecological culture of an individual and its ethical and environmental stance (Krettenauer, Han Dong, etc.) [4; 8]; the environmentally oriented lifestyle of an individual (Fanli Jia, etc.) [3]; the identification of conditions and technologies of ecological culture (M. B. Zatsepina, O. V. Popov and others) [5]; the additional potential ecological culture of an individual in the modern society.

\section{Results}

On the basis of the theoretical analysis, we have identified the students' ecological and legal culture of professional socialization in several ways in the educational practice and the socio-cultural environment of the University.

So, in the direction of the educational practices we have built an interdisciplinary didactic module for universities, including main courses: "Environmental law" and "Ecology of nature" and topics in other disciplines course: "Ecology of the person and literature", "Problems of ecology in the Russian literature of the XX century" (Literature), "Ecological culture in the context of cultural studies, Evolution of culture and ecology", "Environmental factors in the culture development", "Ecological culture in the structure of human activity" (Cultural studies), "The role of ethnic ecology in the study of ancient history by the example of Russia", "Attitude to the nature of historical personalities" (History) and others. This interdisciplinary didactic module activates the students' attention to the relevance of ecological and legal problems, establishes the relationship of ecology with other disciplines and allows creating sustainable environmental value.

Another important direction is a participation in scientific and creative competitions. They are environmental law topics, aimed at the environmental

*Corresponding author: marinabalikaeva@list.ru 
education and the works based on the universal values (morality, honesty, compassion, responsibility and respect for nature, patriotism, tolerance and intolerance for violence), the regional competition of scientific and creative works "let's protect the environment together." The competition "ECO-Lawyer" involves students in practical (essay, process documents) and creative tasks, allows considering in an essay complex issues of scientific and creative nature: the legal protection of water and air, regulation of collection and removal of household waste, problems of illegal dumping, illegal logging, etc. This direction develops not only significant professional qualities (research skills), but cognitive component of the students' ecological and legal culture.

The direction of cultural activities and leisure is provided through the implementation of activities of public associations. In socio-cultural environment of students the disciplines (Social pedagogy, Cultural studies, Sociology) were included in the socio-cultural association "Law, ecologist and me" (2016-2017). In association, there are special environmental-legal actions, flash mobs, aimed at attracting public attention to environmental issues in the urban environment. In this process, the ability to communicate with different population groups developed to prove their own point of view. As an important component of the ecological and legal students' culture is environmental knowledge and students' environmental practices.

The direction of eco-creativity is implemented. Students decorate rooms in a hostel in eco-style. There are fashion demonstrations, displays of body art that link art and environmental focus. The legal component of these directions is optimized by legal information about the limitations of the use of natural resources in creative projects, focuses attention to the balance between the right to creativity and environmental law.

The creative direction and interpersonal interaction in the ecological and legal students' culture is determined by festivals, promotions, etc. For example, students of the information-library faculty, city librarians implement a system of book crossing on the theme "Nature and man". More than 150 publications there are in the buildings of the Chelyabinsk universities.

The dialogue and the exchange of experience between students of the law and economic faculty as well as specialists in various areas of law carried out during participation in the Festival of legal cinema, "The Eyes of Femida" (2014-2017). The festival has legal issues in a creative way. Environmental law is represented at the festival in various genres: documentary movie "CHELYABINSK - the city which could..."; problems of environmental law and air pollution by industrial enterprises; news "Environmental news city $\mathrm{H}^{\prime}$ about environmental problems of the city; the interactive "Stop - closed territory" about violation of citizens ' rights; cartoon "Children's environmental almanac" about types of liability for environmental crimes in the Russian Federation; the cartoon "Grandfather and subsoil" about the rights of citizens to use natural resources: subsoil, water. Students created their video (report, investigation, interview, study film).
Another festival of cinema "Know the right - make a movie!" is an annual legal movie tradition directed on the students interest to the legal regulations and the creation of a movie. In this festival, the environmental problems have been presented during a year of ecology in Russia.

This direction of professional socialization included students in the professional community for selfactualization in the team, systematized knowledge of the ecological and legal culture and implemented the reflexive position of an individual.

\section{Discussion}

The ecological and legal education is a system, which includes all levels of education and advanced training of specialists, aimed at dissemination of knowledge on environmental safety, use of natural resources for the formation of ecological culture. The environmental-legal education purpose is to familiarize with the applicable legislation in the environmental field, developing a deep respect for ecological norms and requirements.

The environmental education in the socio-cultural development includes a development of personal environmental values. The environmental education as a component of socialization is a means of the educational environment in the University [9].

The environmental education determines the opportunities for successful students' socialization in the professional environment. The high ecological culture determines not only the proper understanding of environmental problems, laws of existence and the harmonious development of man in the biosphere, but also the professional socialization in the humanitarian sphere. The relationship of the ecological and legal culture and professional socialization consists of a high level of responsibility, understanding of impacts and the ability to justify and prove their own point of view, the ability to show civil courage.

The main factors of socialization are the following: the impact of society on personality, the social environment, the activity of an individual, the assimilation of knowledge and the understanding, the critical thinking, and the active participation in practical, transforming activity $[10 ; 12]$.

Professional socialization is evident in the readiness of students to implement professional activity and to accept progressive ideas, the mobility in professional activities, the ability for professional development and the continuous professional growth in the field, the focus on good behaviour in a professional environment.

In humanitarian universities, the professional socialization of students is based on psycho-pedagogical features of this social group: the subject creative orientation, the scientific validity of the decisions. The ecological and legal education requires the public consciousness and the individual knowledge in the area of environmental rights, the mandatory execution requirements and the intolerance to the violation of environmental legislation. The ecologic and legal culture is based on understanding culture. 
We investigated the structure of an individual on the following components: ecological and legal knowledge of nature and environmental security, knowledge of the environment, the basics of existing environmental legislation and the use of natural resources to generate environmental culture through socio-cultural institutions (the media, Museum, library, sports and tourism organization); ecological and legal practice, the creative experience of resolving environmental conflict situations; the ecological and legal norms and their requirements, an assessment and forecast of possible environmental changes under the influence of economic and other human activities.

The ecological and legal culture is a special system of social relationships, groups, values, norms and ways of interaction between the individual and the natural environment, the continuity formed in the minds and students' behaviour in the process of education, culture, leisure and practical activities. The basis of ecological and legal culture includes knowledge, skills, values and reflection, a system of interaction of man and nature, which has an impact on the future personal development.

The students' ecological and legal culture is an inclusion in the educational process of interdisciplinary educational programs (E. V. Asafova, K. S. Bakirova, E. V. Kallas, T. P. Solovieva, etc. $[1 ; 2 ; 7])$. Based on research of ecological education, we are of the opinion that the ecological culture of an individual is a sociocultural factor contributing to intelligence and responsibility.

The students' ecological and legal culture of professional socialization in educational practices and cultural and leisure activities has the historical aspects of the ecological education. Environmental education in Russia was an integral part of ethno-upbringing in the family and in the 30-ies of the XX century the ecological education was implemented in the general secondary education. At the end of the 1990 the socio-cultural and scientific theoretical preconditions of the system of ecological education appeared. They included the field of leisure. Its purpose is to create all necessary conditions for the ecological culture of an individual in the extra-curricular education. So, there is a positive practice of professional socialization, the important personal qualities including the students' environmental and ecological and legal culture $[6 ; 11]$.

Hence, the relationship of the ecological and legal culture and the professional socialization is a structure of special socio-cultural and psychological-pedagogical conditions for the students' realization as a part of nature, a mutually beneficial, synergistic action.

The ecological and legal culture is possible outside the classroom that is supported by the students' psychological-pedagogical characteristics, as they take part actively in voluntary associations. The successful ecological and legal education carries out public environmental organizations. In addition, the ecological and legal culture of an individual contributes to the organization of the ecology-educational work in the management institutions: systematic environmental education work; interaction with educational institutions, public authorities; unified information environment, ensuring the availability and exchange of environmental education information; development of the environmental education activities; improvement of the methodical base for effective environmental education work.

The urgency of the problem has a legal level according to article 71 of the Federal law of 10 January 2001 No. 7 "The environmental protection" [3; 13]. The ecological culture in Russia must have a comprehensive and universal system of ecological education. The environmental education system should have both the general education and the professional education, which include secondary and higher education and additional professional education of specialists. Thus, the environmental education should have almost the entire structure of the education system. The only exception is the additional education of children. It is not included in the system of comprehensive environmental education, which in our opinion is unreasonable, violates the statutory principle of systematic environmental education.

The ecological and legal education is possible to train after lessons. This education is supported by the psychological and pedagogical characteristics of students as special age groups participating in social groups. Currently, the environmental education is an activity of quite successful public environmental institutions. In addition, the systematic environmental and educational activity contributes to the effective formation of an ecological and legal personality culture.

The public ecological institutions protect natural territories. Their activity includes systematic ecological and educational activity with various groups of citizens, including students. The public ecological institutions interact with educational institutions, public authorities; ensure the availability and exchange of environmental educational information. These institutions make a material and technical base of environmental education; improve the methodological base for effective ecological education activity.

The formation of the ecological and legal students' culture is a complex socio-cultural and psychologicalpedagogical problem related to the search promising areas and technologies in the educational environment.

The educational environment allows students to regulate the competitiveness of professional and social activities. An important direction in solving the problem of the effective formation of an environmental legal culture is the use of the potential of the leisure of students in the system of public institutions.

The formation of ecological and legal students' culture is in the aspect of professional socialization. There are factors of studying the problem. The factors are political, institutional, psychological and pedagogical. The development of ecological and legal students' culture is in the socio-cultural environment through the leisure students' activities and the system of public institutions. 


\section{Conclusion}

The ecological and legal students' culture is a sociocultural and psycho-pedagogical problem of perspective directions and technologies in educational environment. It improves the competitiveness of students in professional and social activities. An important direction of the ecological and legal culture is to use the potential of cultural and leisure environment of the University, incorporating students into the system of public associations and organizations, understanding of the ecological and legal culture as an integral part of the culture of a professional.

\section{References}

1. E.V. Asafova, H. Uzunboylu. Proc. Social and Behavioral Science; 2014 Feb 06-09; The Development of Ecological Culture of Students in the Design and Creative Activity, Proc. of 6th World Conf. on Educational Sciences. 191 (2015)

2. K.S. Bakirova, A. Seilkhan. Methodological Bases Formation Of Ecological Culture For Students Of Pedagogical High School. JG Laborda, 4th (WCLTA). Proc. Social and Behavioral Sciences, 141 (2013)

3. F.L. Jia, K. Soucie, S. Alisat, D. Curtin, M. Pratt, Jour. of envir. psychol. Are environmental issues moral issues? Moral identity in relation to protecting the natural world, 52 (2017)

4. D. Han, J.K. Hung, R. Fan, H. Zhao, Research on Ecological Moral Education in the Course of "Ideological and Moral Cultivation and Legal Basis" Thinking of Strengthening the Education of College Students' Ecological Civilization Awareness", Dunhuang, Peoples R China, Proceedings of the sixth international symposium: education innovation and dunhuang culture engineering, (2013)
5. M.B. Zatsepina, O.V. Popova, A.V. Filippova, I.V. Muskhanova, A.K. Yakhyaeva, A.M. Ishmuradova, Euras. Technologies of Students Ecological Culture Formation, Jour. of anal. chem., Conditions and 12 (5B) (2017)

6. E. Yu. Malushko, O. A. Maletina, and V. A. Tsybanyova, Teaching Learners to Exchange Information over the Telephone, SHS Web of Conferences, 50, 01188 (2018)

7. Y.J. Zhang, P. Chen, S. Zhang, 2nd (ICEMCT, ASSEHR), Analysis on Significance of Campus Culture Activity in Political and Ideological Education of Universities, Tianjin, Peoples R China, 30 (2015)

8. E.V. Kallas, T.P. Solovjeva, L.Y. Minakova, Implementation of Ecological Education in a Higher School, 26th Int. Academic Conf. on Language and Culture, 200 (2015)

9. T. Krettenauer, Pro-Environmental Behaviour and Adolescent Moral Development,Jour. of research on adolescence, 27(3) (2017)

10. L.N. Rebrina, E.Yu. Malushko, ASSEHR, Representation of the mnemic process of "memorization" in German: constant features, 97, (2017)

11. A. Lukina, D. Malova, V. Kuznetsov, The analysis of ecological culture and behaviour of students and employees in Russian university, Economic Science for Rural Development, 45, (2017)

12. S. Riddle, Ecological Congruence and the Identification of Learning Disabilities, Child \& youth care forum, 46 (2), (2017)

13. M.A. Suzdalova, V.G. Lizunkov, E.Yu. Malushko, N.A. Sytina, V.E. Medvedev, Innovative Forms of Partnership in Development and Implementation of University-Business Cooperation, EpSBS, 19 (2017) 